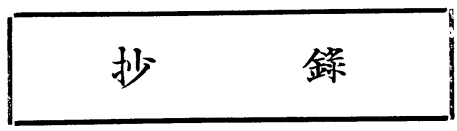

\title{
齿 科 外科埋伏上顎犬齔找去ノ適應症
}

Die Indikation zur Entfernung retinierter oberer Eckzähne von Dr. Richard Trauner Z. f. S. 1934. Heft 22.

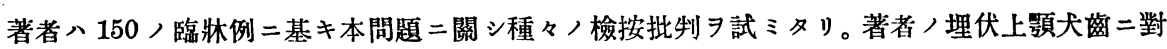

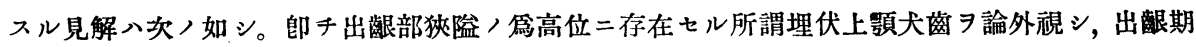

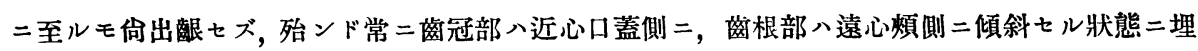

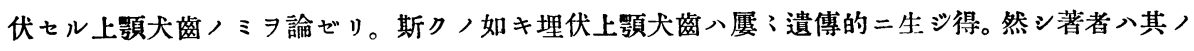
$\% \ni$ 確認シ得ル程多數 $\exists$ 觀察シ得ブ。一般二埋伏齒牙卜同時二且ッ同部位二腫瘍, 存在セル場合

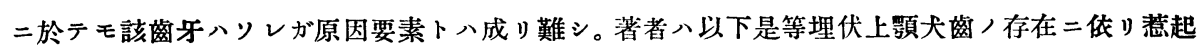
セラレ得ル種々ノ障碍ヨ詳述セルモ大約セバ,

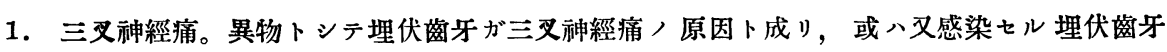
, 冠周間隙ヨリ三叉神經痛ヨ㺃起スト言フ境八首肯セラレ得ルモ, 實際二著者, 臨牀例二於テ埋 伏蒛牙, 存シ, 且ッ同時ニ三叉神經痛, 症狀 $コ$ 呈セル例八然ラザル例 ヨリ少數ナリト報告セリ。

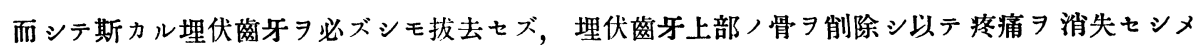
得タリ。

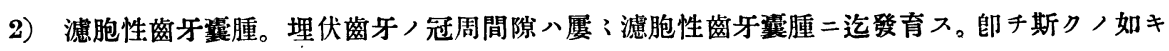

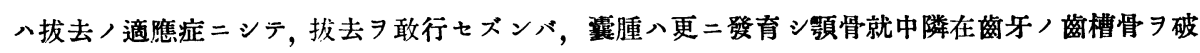
壞シ, 終局八口腔卜連絡化膿スルニ至ル。

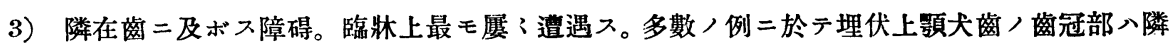

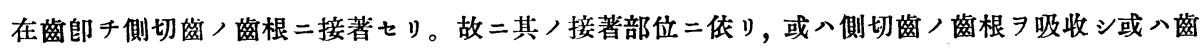

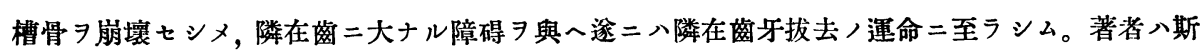

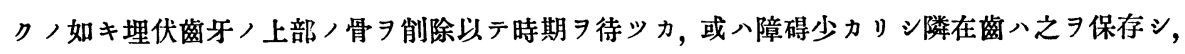

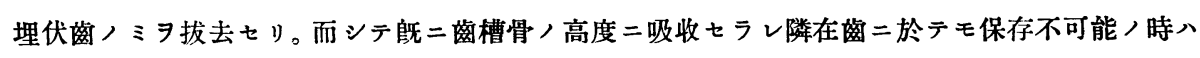

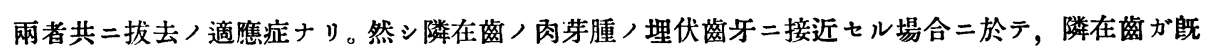

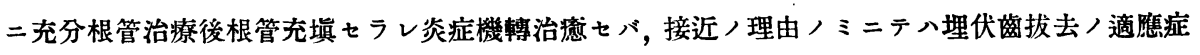
ニ成り難シ。

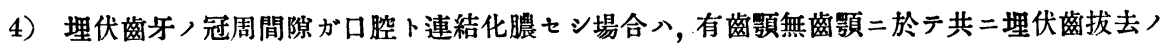
適應症ナリ。斯ク，如キ 7 放置セパ, 腫脹, 膿瘍, 瘻孔形成ノ過程 7 反復ス。此, 際腐骨 7 伴ナ 


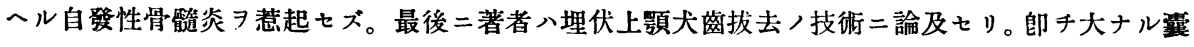

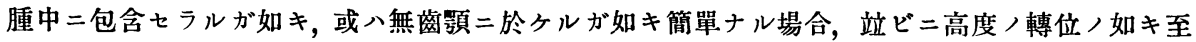
難ノ場合 7 論外トナシ，保存 $ᄏ$ 希望セル隣在齒/齒根二接近セル場合, 或ハ口蓋骨中ノ深部二埋

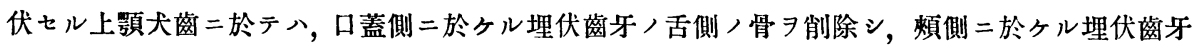
ノ根端部 7 露出セシメ, 然ル後根端部 $フ$ 口蓋側方向二槌打スル方法 7 推獎セリ。(高橋正太郎)

\section{濾胞性䠛牙軎腫}

Follikuläre Zyste

von Dr. F. I. Lapidus(Zeitschrift für Stomatologie, 1934, Heft 22)

炎症恱ヨ主張セル者八著省

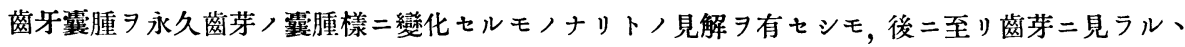
變化八其ノ外上皮ニノミ起ルモノニシテ, 健全ナル蓄牙八障碍ヨ受ケシ薑芽ョリ生ズル事八稀ナ リト稱セリ。之二反シ Brocca, L. Cohn 等八發生學說习主張シ, Brocca 八最モ古クョリ濾胞性

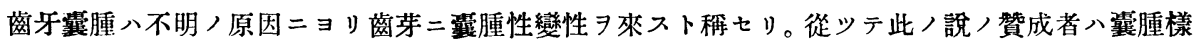
二戀化セル菌芽ハ手術二際シ囊腫ト共二摘出スベキ事ヨ主張ス。其他 Issajew, Bloci-Jeorgenson 等ノ研究有り。著者ハ $\mathrm{X}$ 線二依ル檢查, 結果次ノ如ク要約セり。師チ(1)滤胞性齒牙囊腫八槛患

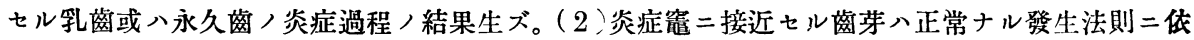
リ發育ス。此ノ際畸型ヨ來ス事アリ。(3)手術部位ニ存スル蒛芽八拔去ス可カラズ。一般二八滤

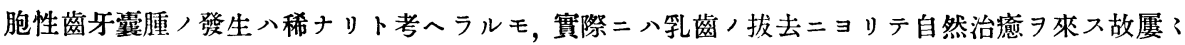

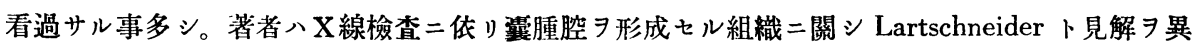

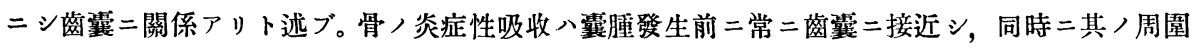

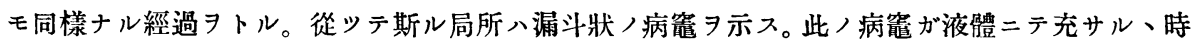

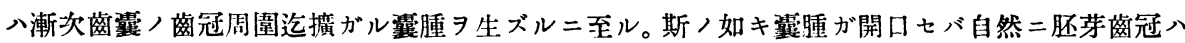

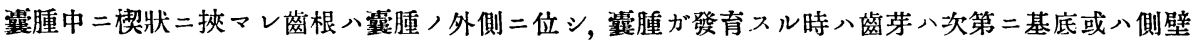
二壓迫サルニ至ル。

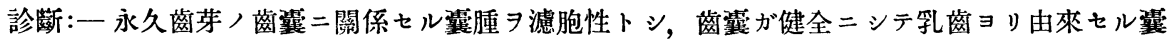

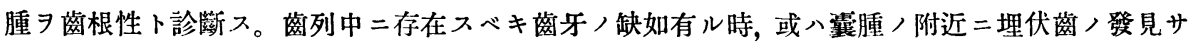
レシ時等ニ八濾胞性, 疑有り。向囊腫樣ノ失調症卜時二誤診セラル。故二X線檢索ヨ必要卜ス。 治療及豫防法:一過程, 如何二依り種々ノ外科的手術ヨ行フ。郎チ小ナル囊腫八除去シ原因タ

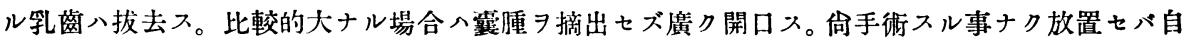
然骨折或八上頻簤內へ八增殖

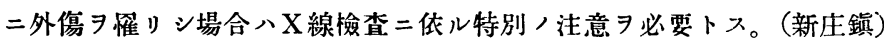

